\title{
SIKAP GURU BIMBINGAN KONSELING SMA NEGERI DKI JAKARTA TERHADAP LGBT (Lesbian, Gay, Biseksual dan Transjender) DI SEKOLAH
}

\author{
Susi Fitri ${ }^{1}$ \\ Meithy Intan Rukia Luawo ${ }^{2}$ \\ Wuri Tarzia ${ }^{3}$
}

\begin{abstract}
Abstrak
Penelitian ini bertujuan untuk memperoleh gambaran sikap guru Bimbingan Konseling SMA Negeri DKI Jakarta terhadap LGBT (Lesbian Gay Biseksual Transjender) di sekolah. Populasi dalam penelitian ini adalah guru Bimbingan Konseling SMAN DKI Jakarta baik lulusan S1 Bimbingan Konseling maupun bukan lulusan S1 Bimbingan Konseling. Sampel dalam penelitian sebanyak 86 guru Bimbingan Konseling yang terdiri dari 18 orang laki-laki dan 68 orang wanita.Teknik sampling pada penelitian ini menggunakan teknik Multistage Random Sampling.Pengumpulan data diperoleh menggunakan Kuesioner yang terdiri dari 72 pernyataan yang dikembangkan berdasarkan skala sikap Riddle. Skor Reliabilitas pada instrumen yaitu 0.93 yang berarti instrumen Reliabel dan dapat dipercaya. Hasil penelitian menunjukkan bahwa kecenderungan sikap guru Bimbingan Konseling SMAN di DKI Jakarta terhadap LGBT di sekolah lebih negatif dengan presentase sebanyak 68,6 persen dari populasi, Repulsion (menolak) adalah jenis sikap dengan persentase tertinggi yang dipilih oleh sebanyak 44,07 persen responden yang memiliki sikap negatif. Laki-laki memiliki sikap negatif lebih tinggi dengan presentase 77,77 persen dibandingkan dengan perempuan dengan persentase 68,16 persen. Hasil tersebut memberikan implikasi bahwa keberadaan LGBT yang mengalami penolakan dan diskriminasi dalam lingkungan, tidak mendapatkan cukup bantuan, selain itu hal ini berdampak pada ketepatan dan keefektifan pelayanan yang akan diberikan oleh guru Bimbingan Konseling di sekolah. Guru Bimbingan Konseling perlu mengembangkan sikap yang lebih positif terhadap LGBT di sekolah, dengan cara mengikuti seminar atau pelatihan untuk konseling terhadap LGBT, serta membaca beberapa buku yang berkaitan dengan layanan yang dapat diberikan pada LGBT di sekolah.
\end{abstract}

Kata kunci: Sikap, Homoseksual, Lesbian, Gay, Biseksual, Transjender, Skala Riddle, guru Bimbingan Konseling.

\begin{abstract}
This research aimed to abtain information about attitudes of high school counselor toward LGBT at schoolS in DKI Jakarta. The population of this research was high school counselors in SMAN DKI Jakarta either graduated or not graduated

\footnotetext{
${ }^{1}$ Dosen Program Studi Bimbingan dan Konseling FIP UNJ, susi.fitri@unj.ac.id

2 Dosen Program Studi Bimbingan dan Konseling FIP UNJ, meithy intan@yahoo.com

${ }^{3}$ Mahasiswa Program Studi Bimbingan dan Konseling FIP UNJ, tarziawuri@gmail.com
} from guidance and counseling major. The sample in this research was 86 teachers guidance and counseling which consists of 18 is men and 68 is women. The sampling technique used in this research was Multistage Random Sampling techniques. Data collection tool used was questionnaire that consists of 72 items based on the Riddle scale.Reliability score of the instrument was 0.93 which means that this instrument 
has a very high reliability and trustworthy. The result of the research showed attitudes of high school counselors toward LGBT at schools in SMAN DKI Jakarta is more negative with a 68,6 percent from population, repulsion is a kind of negative attitude as the highest percentage of as much as 44,07 percent. Men have a higher percentage of the negative attitude with percentage 77.77percent compared to women with percentage 68,16 percent. The result gives the implication that presence of LGBTexperience rejections and discriminations in their environment, not enough to get help at school, in addition it is impacting on the appropriateness and effectiveness of theservices to be provided by school counselor. School counselors need to develop their attitudes to be more positive toward LGBTat school by following seminars or trainings for counseling with $L G B T$ and read several books that related to provide services for LGBT at school.

Keywords: Attitude, Homosexual, Lesbian, Gay, Bisexual, Transgender, Riddle Scale, School Counselor.

\section{PENDAHULUAN}

Pro kontra mengenai LGBT mendorong masyarakat untuk memberikan respon kepada LGBT, respon dari pihak-pihak kontra ditunjukkan dengan beberapa perilakuperilaku yang mendiskriminasi baik dengan pembatasan akses/layanan, hingga beberapa kekerasan yang mempengaruhi kesehatan mental LGBT.

Kelompok kontra merupakan orangorang yang sangat menolak LGBT (Lesbian Gay Biseksual dan Transjender), Kelompok kontra biasa disebut sebagai seorang yang homophobia atau transfobia. Walaupun homofobia dan transfobia merupakan kecenderungan sikap negatif yang menetap karena ketakutan irasional terhadap homoseks dan transjender, penelitian Schiffman dkk menemukan bahwa kata homophobia merupakan perluasan makna bagi orang-orang yang berprasangka terhadap LGBT (Tollerud \& Slabon, 2009).

Kekerasan yang dialami oleh LGBT tidak hanya dialami dalam lingkungan masyarakat, namun juga pada lingkup sekolah. Kekerasan yang dialami LGBT sebagian besar merupakan tindakan bullying di sekolah. UNESCO (United Nations Educational, Scientific and Cultural Organization) menyebutkan bahwa homophobic bullying merupakan tindakan yang dilakukan terbanyak kedua diseluruh dunia (Laazulva, 2013).
Kekerasan akibat homophobic bullying dalam area pendidikan dialami oleh 30 hingga 50 persen LGB (Lesbian Gay Biseksual) di Inggris, Australia dan Amerika (Warwick \& R. Goodrich, 2006). Dua dari lima siswa transgender, dan satu dari lima siswa LGB dilaporkan mengalami kekerasan fisik atas ekspresi gender mereka. Hal ini menjadi sangat serius dengan temuan lain yaitu sebanyak 47 persen staf sekolah tidak melakukan tindakan ketika komentar buruk ditujukan kepada transgender, dan 34 persen pada LGB (Tayor \& Petter, 2009).

Kekerasan yang dialami oleh LGBT akan mempengaruhi kesehatan mental yang mereka miliki. Sanders mengungkapkan bahwa pengalaman menjadi korban bullying pada siswa akan mempengaruhi kesehatan fisik dan mental, mendorong perilaku bunuh diri, serta pengkonsumsian alkohol dan obat-obatan (Davis, 2006).

Senada dengan pernyataan Sanders, Warwick mengemukakan secara umum pengalaman menjadi korban bullying diyakini akan memberikan dampak, seperti, malu, cemas, takut, tertekan dan hal negatif lainnya terhadap seseorang. Ia menambahkan bullying dalam bentuk verbal, maupun fisik akibat homophobia yang dialami remaja yang mengidentifikasi diri sebagai LGBT memberikan dampak negatif, seperti pengabaian dalam mengikuti pendidikan, cemas, hingga bunuh diri. Hal ini membuat kasus percobaan bunuh diri pada 
remaja LGBT lima kali lebih besar daripada remaja normal lainnya (Warwick \& R. Goodrich, 2006)

Berkaitan denggan LGBT di sekolah, pihak yang mungkin melakukan advokasi terhadap LGBT ialah guru BK. Dukungan dari Staf sekolah dan pengajar sangat diperlukan dalam mengatasi kekerasan berbasis jender yang ada didalam masyarakat yang chauvinisme heteronormatif (Rinehart \& Espelage, 2016).

Terkait dengan isu multikultur dan masalah LGBT. Penelitian mengenai sikap juga sebagai bentuk asesemen diri mengenai kemampuan guru dalam kompetensi multikulturnya yaitu berkaitan dengan identifikasi diri konselinya, penyadaran akan sikap yang dimiliki terhadap kelompok LGBT yang mungkin berakibat pada bias dalam pelaksanana layanannya. Layanan Bimbingan Konseling komprehensif oleh guru Bimbingan Konseling dilakukan dengan memberikan pelayanan pencegahan untuk tindakan homofobia seperti diskriminasi, bullying, queerbashing, dll, membantu penyelesain permasalahan yang dimiliki oleh LGBT di sekolah seperti pencegahan bunuh diri, depresi, serta menciptakan sistem yang mendukung program anti bullying di sekolah. Penelitian mengenai sikap guru Bimbingan Konseling terhadap LGBT di Indonesia tidak dapat ditemukan oleh peneliti.

Dengan mengukur sikap, kita dapat melihat kecenderungan perilaku guru Bimbingan Konseling dalam membantu LGBT terkait permasalahan yang dihadapinya. Hal ini sesuai dengan definisi bahwa sikap merupakan kecenderungan sesorang dalam berperilaku. Meskipun demikian didalam penelitan sebelumnya telah diungkapkan bahwa sikap akan tampak sebagai suatu perilaku ketika lingkungan mendukungnya (Edwards, 1957), namun ketika ia memiliki kesempatan atau mungkin guru Bimbingan Konseling dapat menciptakan kesempatan dalam memberikan layanan yang ramah LGBT.

\section{ACUAN TEORITIK}

Pelaksanaan layanan bimbingan komprehensif, bertujuan membantu konseli dalam mencapai perkembangan yang optimal dan memandirikan dalam aspek pribadi, belajar, sosial dan karir.

Menurut Muro dan Kottman Layanan Bimbingan Konseling Komprehensif terbagi atas empat layanan yang terdiri atas layanan dasar, layanan responsif, layanan perencanaan siswa, serta layanan dukungan sistim (Yusuf \& Nurihsan, 2011)

Guru bimbingan Konseling perlu memiliki beberapa kompetensi, diantaranya adalah kompetensi multikultur. Kompetensi multikultural terbagi atas 3 hal. pertama memfasilitasi seseorang untuk dapat bekerja secara efektif dengan orang lain yang dianggap memiliki budaya yang berbeda dari kebanyakan, memfasilitasi seseorang untuk mengembangkan diri sendiri dan orang lain berkaitan dengan kesadaran dan pengetahuan serta mengembangkan keterampilan berbudaya dengan tepat (Tollerud \& Slabon, 2009).

Sue dkk (2005) mendefinisi-kan 3 hal yang berhubungan dengan konselor multikultur, pertama, sadar tentang sikap dan nilai yang dimiliki dalam ras dan etnis lingkungan sekitar, kedua, mengembangkan pengetahuan tentang keragaman budaya serta pengalaman, dan yang ketiga mengidentifikasi keterampilan efektif dalam dan memulai bekerja dengan klien kulit berwarna (Constantine \& Sue, 2005).

Dinamika yang dialami oleh LGBT, sebagai kelompok yang diminoritaskan dan dianggap menyimpang sangat mungkin dihadapi oleh konselor. Hal ini menuntut keprofesionalan konselor dalam menghadapi klien yang berhubungan dengan LGBT. Pemaknaan seksualitas dan identitas LGBT oleh konselor dipegaruhi oleh beberapa faktor, seperti sikap, nilai-nilai, kayakinan, stareotip, peran jender, agama, asimilasi budaya, dan dukungan masyarakat. Perlunya kesadaran akan hak istimewa terhadap heteroseksual 
perlu ditingkatkan, serta mendengarkan dan belajar dari kehidupan orang lain (Tollerud \& Slabon, 2009).

Dalam pelaksanaan konseling, budaya berpengaruh pada pendefisian masalah klien. Konselor memerlukan ketelitian dalam pelaksanaan assesmen berkenaan dengan perbedaan budaya. Hal ini untuk menghindari ketidak sesuaian pengukuran bagi klien (Suzuki \& Ponterotto, 2008).

Konselor perlu berhati-hati dalam melakukan assemen pada populasi normal pada pada kliennya, mengenali efek usia, budaya, kecacatan, etnis, jenis kelamin, ras, prefensi, bahasa, agama, spriritualitas, orientasi seksual dan status ekonomi diperlukan dalam melihat cara pandang dan penginterpretasian yang tepat untuk masalah klien (Suzuki \& Ponterotto, 2008).

Sikap merupakan kecenderun-gan seseorang berperilaku atas dasar pertimbangan dari pengalaman yang dimiliki yang bersifat baik positif maupun negatif terhadap objek sikap. Sikap dibentuk oleh 3 komponen utama yaitu (Sarwono \& Meinarno, 2009; Soekrisno \& Adryanto, 1999; Gerungan, 2004):

1. Kognitif yaitu kumpulan respon dari persepsi reaksi, ide dan pemikiran, tanggapan, keyakinan, kesan, atribusi dan penilaian tentang objek. (Ajzen, 2005; Sarwono \& Meinarno, 2009; Soekrisno \& Adryanto, 1999).

2. Afektif yaitu keseluruhan perasaan suka atau tidak suka, senang atau tidak senang atau emosi seseorang terhadap objek sikap. (Ajzen, 2005; Sarwono \& Meinarno, 2009; Soekrisno \& Adryanto, 1999)

3. Konatif atau disebut sebagai kecenderungan perilaku yaitu kesiapan untuk beraksi, atau kecenderungan dalam melakukan tindakan atau perbuatan, yang dapat diketahui melalui respon subyek yang berkenaan dengan objek sikap berupa intensi atau niat untuk melakukan perbuatan tertentu. (Ajzen, 2005; Soekrisno \& Adryanto, 1999; Sarwono \& Meinarno, 2009).
Berdasarkan definisi sikap sebagai evaluasi yang bertingkat antara positif dan negatif terhadap objek sikap yang dimiliki oleh seseorang, maka sikap dibagi menjadi dua bentuk sikap. Dua bentuk sikap yaitu sikap positif dan sikap negatif (Arifin, 2015)

Sikap positif dapat berupa kerjasama, tanggang rasa, dan melihat keadaan orang lain. Sedangkan sikap negatif dapat berupa egoisme, prasangka sosial, rasisme, dan stereotip (Arifin, 2015)

Sikap terhadap LGBT diukur menggunakan Skala sikap homophobia Riddle. Skala yang dirancang untuk menjelaskan kontinum sikap terhadap gay dan lesbian ini, sering digunakan dalam pendidikan toleransi mengenai sikap anti diskriminasi terhadap orientasi seksual (Evans \& Wall, 1991; Riddle D. I., 1994; Bishop, Williams, Currie, Kaplan, \& Luehr, 1994; Riddle B., 1996; Schreier \& Lassiter, 2010; Sue \& Sue, 2013) Skala Riddle terbagi atas dua jenis sikap dengan tingkatan tertentu yaitu:

1. Sikap Negatif yang terbagi atas:

a. Repulsion (Menolak): homoseksual, biseksual, transjender dan jender yang tidak jelas dipandang sebagai "kejahatan terhadap alam". Mereka dianggap sakit, gila, tidak bermoral, berdosa, jahat, dan sakit mental dll. Anggapan tersebut menjadikan kita bertugas untuk mengubah mereka kembali ke arah yang benar. Apapun dibenarkan untuk mengubah mereka baik secara medis, maupun memaksa dengan pemenjaraan, pengurungan, rawat inap, konversi atau pengubahan orientasi, terapi aversif, kejut listrik, terapi perilaku, serta kekerasan dan lainnya. Pada kasus internalisasi homophobia/ transpobia, seseorang homoseksual maupun transjender akan menolak terus menerus dirinya, menyalahkan dirinya dan sangat membenci orang yang mengingatkannya pada dirinya sendiri. Kasus ekstrem dalam internalisasi homophobia dilakukan oleh seseorang yang sebenarnya gay, memiliki sikap yang sangat negatif akan sangat aktif dan 
agresif dalam memaksa orang lain untuk merubah orientasi seksual/identitas yang dimiliki (Lock \& Kleis, 1998).

b. Pity (Mengasihani): merupakan chauvinisme heteroseksual maupun role jender biner dimana peran jender tradisional dan heteroseksual dilihat sebagai hal yang lebih baik, lebih matang dan lebih disukai. Kemungkinan menjadi "lurus", "heteroseksual" atau "normal" harus diperkuat. orang-orang yang tampaknya sebagai Gay, Lesbian, Biseks dan Transjender yang terlahir seperti itu harus dikasihani karena kurang beruntung dan perlu dikasihani karena mereka tidak bisa menjadi peserta penuh dalam kehidupan sosial dan budaya, itu terlihat seperti cacat yang harus mereka alami dalam hidup. Tujuan kita untuk membantu mereka menjadi sebagai "senormal" mungkin, dan memperlakukan mereka dengan beberapa kebaikan..

c. Tolerance (Menoleransi): homoseksual, biseksual, transjender dan jender yang tidak jelas adalah sebuah fase perkembangan remaja yang dilalui banyak orang dan kebanyakan orang tumbuh dari kondisi tersebut. homoseksual, biseksual, transjender dan jender yang tidak jelas adalah orang yang kurang matang daripada heteroseksual, mereka harus dilindungi dan diperlakukan seperti seorang anakanak. Mereka tidak boleh diberikan kedudukan kekuasaan karena mereka masih menjalani perilaku remaja mereka. Dengan anggapan demkian maka para LGBT tidak memperoleh haknya dalam menjalani profesi tertentu misalnya guru sebagai profesi yang dianggap lebih matang dibandingkan muridnya. Tidak dapat menjadi ketua dalam organisasi maupun berbagai posisi yang dianggap sebagai posisi yang memimpin. Seperti halnya dalam pembatasan akses dalam penelitian Stonewall (Yuliani, 2013).

d. Acceptance (Menerima): Heteroseksual perlu membuat akomodasi untuk homoseksual, biseksual, transjender dan jender yang tidak jelas. Sikap ini tidak berarti bahwa homoseksual, biseksual, transjender dan jender yang tidak jelas diakui memiliki nilai yang sama dan penting sebagai seseorang, tetapi jelas bahwa mereka memiliki kehidupan dan hak untuk hidup. hal ini masih menyiratkan bahwa ada sesuatu untuk diterima. Masih terdapat diskriminasi dalam bentuk pengabaian hal ini ditandai dengan pernyataan seperti "ini adalah sikap terbaik saya"; "saya tidak berpikir Anda sebagai seorang gay"; "Saya pikir Anda adalah orang yang seperti saya"; "Anda tidak lesbian/gay/trans kepada saya, Anda orang!”; "apa yang Anda lakukan di tempat tidur adalah bisnis Anda sendiri" atau "Itu baik-baik saja dengan saya selama Anda tidak memamerkannya!", memamerkan dalam hal ini adalah melakukan suatu perilaku/ perkataan yang menyiratkan bahwa ia adalah bagian dari LGBT.

5. Sikap Positif yang terbagi atas:

a. Support (Mendukung): Orang-orang LGBT pantas mendapat perlindungan hukum dan hak-hak sipil sebagai kelompok minoritas atau kelompok yang dilindungi. Terlepas dari masalah moral dan kenyamanan sendiri dengan homoseksualitas, setiap orang harus memiliki hak-hak sipil dan akses yang sama, dan harus diperlakukan dengan adil serta kebebasan sipil yang sama. Orang-orang ditingkat ini mungkin tidak nyaman sendiri, tetapi mereka sadar bahwa homofobia, iklim homophobic, batasan terhadap jender dan ketidakadilan irasional adalah salah dan mereka bekerja untuk melindungi hak-hak homoseksual, biseksual, transjender dan jender yang tidak jelas. Menurut Riddle dukungan sosial akan membantu seseorang untuk menyadari jaringan sosial dan membangun strategi dalam mengembangkan dirinya (Ward \& Riddle, 2014).

b. Admiration (Mengagumi): Mengakui bahwa menjadi homoseksual, biseksual, transjender dan jender yang tidak jelas di dalam masyarakat membutuhkan sejumlah besar kekuatan dan keberanian. Oleh karena itu, mereka layak dikagumi. Orang pada tingkat ini bersedia untuk benar-benar menguji ideide mereka sendiri tentang jender, sikap homophobic, nilai-nilai, dan perilaku 
mereka sendiri.

c. dalam proses coming out yang cukup menyulitkan, mereka pantas untuk dikagumi sebagai seseorang yang berani menerima dirinya, bangga akan dirinya sendiri. Coming out adalah istilah bagi LGBT yang menerima diri, terbuka, jujur terhadap identitas dan orientasi seksual yang dimiliki (Allen, 2010). Berbagai asumsi mengenai cara coming out dilakukan, bahwa seseorang dikatakan sudah coming out dengan cara menyatakan diri sebagai LGBT didepan banyak pihak atau hanya menyatakannya pada beberapa pihak saja, misal keluarga. Namun intinya adalah proses ini hanya akan dilakukan oleh orang-orang yang matang, berani mengambil resiko untuk ditolak dengan sistim heteronormatif yang ada, dan orang yang menerima dirinya sebagai manusia yang utuh (Raharjo, 2007; Wong, 2007).

d. Appreciation (Menghargai): menghargai keragaman orang adalah hal yang baik. menghargai keragaman orang - orang homoseksual, biseksual, transjender dan jender yang tidak jelas sebagai bagian dari keragaman yang ada. Orang - orang ini bersedia untuk memerangi prasangka berbasis jender dan homofobia baik pada diri sendiri maupun orang lain.

e. Nurturance(Mengasuh):mengasumsikan bahwa orang-orang homoseksual, biseksual, transjender dan jender yang tidak jelas sangat diperlukan, dicapai, dan bagian yang penting dalam masyarakat. Mereka melihat homoseksual, biseksual, transjender dan jender yang tidak jelas dengan tulus, menyenangkan, sebagai kolega, dan rekan, pro-aktif dalam berdebat untuk hak-hak mereka, prestasi mereka dan kemanusian mereka dalam semua keutuhan dan bersedia menjadi sekutu dan advokat. Sekutu bagi LGBT, membantu meningkatkan prestasi dan pendidikan LGBT, mereka bisa termasuk bagian dari LGBT maupun non LGBT. Sekutu yang merupakan non LGBT biasanya berasal dari lingkungan LGBT tersendiri seperti teman, kerabat, keluarganya (biasanya ibu) dan beberapa civitas akademisi. Iklim yang sangat heteronormatif membuat orang-orang ini dianggap sebagai orang aneh bagi
nonLGBT mereka sering mengira bahwa pembela LGBT adalah bagian dari LGBT itu sendiri, disisi lain para LGBT akan merasa curiga dan sulit mempercayai keheteroseksualan yang dimiliki pembela LGBT ini sendiri (Wong, 2007).

Terkait dengan sikap terhadap LGBT, beberapa peneliti menemukan faktor-faktor yang mempengaruhi sikap seseorang terhadap LGBT(Crooks \& Baur, 2011; Boxill, Galbraith, Mitchell, \& Russell, 2012) yaitu:

- Fobia: ketakutan irrasional terhadap LGBT, diantaranya dimana seseorang yang sebenarnya adalah homoseks ataupun transjender menolak identitas dan orientasi yang dimilikinya.

- Jenis kelamin: ditemukan bahwa seorang laki-laki memiliki sikap yang lebih negatif dibandingkan dengan perempuan.

- Religiusitas: dogma agama akan mempengaruhi seseorang untuk bersikap terhadap suatu hal, dalam hal ini tindakan LGBT dianggap sebagai dosa dan menyalahi kodrat manusia.

- Pengetahuan: pengetahuan seseorang mengenai teori -teori dalam pembantukan orientasi dan identitas seksual seseorang, akan mempengaruhi sikap orang tersebut terhadap LGBT.

- Pengalaman dalam berinteraksi: seseorang yang memiliki pengalaman berinteraksi secara positif dengan LGBT lebih mungkin memiliki sikap positif terhadap LGBT dibandingkan orang yang memilki trauma ataupun tidak memiliki pengalaman dalam berinteraksi dengan LGBT

\section{METODOLOGI PENELITIAN}

Penelitian ini dilakukan pada guru Bimbingan Konseling SMA Negeri di DKI Jakarta baik lulusan S1 Bimbingan Konseling ataupun alih jurusan.

Tujuan penelitian ini adalah untuk memperoleh gambaran sikap guru Bimbingan Konseling SMA Negeri DKI Jakarta terhadap LGBT (Lesbian Gay Biseksual Transjender) di sekolah. 
Populasi dalam penelitian ini adalah guru Bimbingan Konseling di Sekolah Menengah Atas Negeri DKI Jakarta yang tersebar secara tidak merata pada lima Wilayah, yaitu Jakarta Pusat, Jakarta Utara, Jakarta Timur, Jakarta Selatan, dan Jakarta Barat

Penelitian ini menggunakan pendekatan kuantitatif dan metode yang digunakan adalah deskriptif dengan jenis survei. Sampel yang diperoleh dengan menggunakan rumus Slovin adalah sebanyak 86 dari 379 guru Bimbingan Konseling SMA Negeri DKI Jakarta. Pengambilan sampel ini diikuti dengan penggunaan metode Multistage Random Sampling perpaduan antara probability sampling dengan teknik propotional random sampling.

Teknik pengumpulan data menggunakan instrumen skala sikap Riddle .Skala pengukuran yang digunakan adalah skala Guttman dengan dua pilihan jawaban, yaitu ya atau tidak. Analisis data menggunakan statistik deskriptif dengan teknik presentase. Sebelum penghitungan presentase, terlebih dahulu dianalisis berdasarkan kategorisasi bukan jenjang (nominal).

Responden akan dikategorikan dalam kelompok tertentu berdasakan nilai z terbesar yang dimilikinya.Rumus yang digunakan untuk mengkategorisasikan data yaitu sebagai berikut:

$$
\begin{aligned}
& \mathrm{Z} \text { score }=\frac{x-\mu}{\mathrm{SD}} \\
& \begin{array}{l}
\text { Keterangan: } \\
x=\text { skor responden } \\
\mu=\text { Mean jenis }
\end{array} \\
& \underline{\mathrm{Sd}}=\underline{\text { standar deviasi }} \\
& \underline{\mathrm{Sd}}=\sqrt{\frac{\Sigma(x-\mu)^{2}}{\mathrm{n}-1}} \\
& \begin{array}{l}
x=\text { skor responden } \\
\mu=\text { Mean } \\
\mathrm{n}=\text { responden }
\end{array}
\end{aligned}
$$

HASIL PENELITIAN
Berdasarkan penyebaran instrumen Sikap Guru Bimbingan Konseling Sma Negeri Dki Jakarta Terhadap Lgbt (Lesbian, Gay, Biseksual Dan Transjender) di Sekolah mengguunakan skala Riddle yang berisi 72 butir pernyataan diperoleh hasil sebanyak bahwa $59 \quad(68,6 \%)$ responden memiliki kecenderungan sikap negatif terhadap LGBT (Lesbian Gay Biseksual Transjender) di sekolah, 27 (31,4\%) lainnya memiliki memiliki sikap positif terhadap LGBT (Lesbian Gay Biseksual Transjender) di sekolah.

Adapun hasil secara rinci dapat disajikan pada gambar berikut:

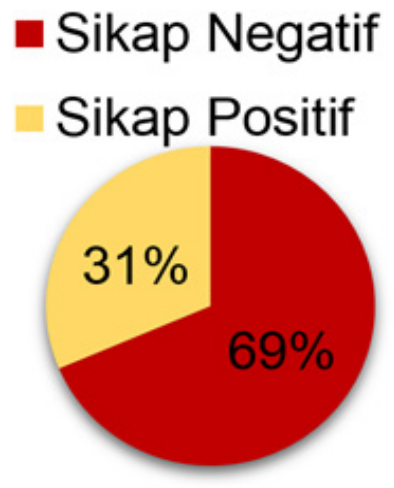

Gambar 1. Sikap guru Bimbingan Konseling SMAN DKI Jakarta

Berdasarkan gambar1. Hasil pengolahan instrumen sikap guru Bimbingan Konseling menunjukkan bahwa 59 (68,6\%) responden memiliki kecenderungan sikap negatif terhadap LGBT di sekolah, 27 (31,4\%) lainnya memiliki memiliki sikap positif terhadap LGBT (Lesbian Gay Biseksual Transjender) di sekolah. 


\section{Repulsion Pitty}

\section{Tolerance Acceptance}

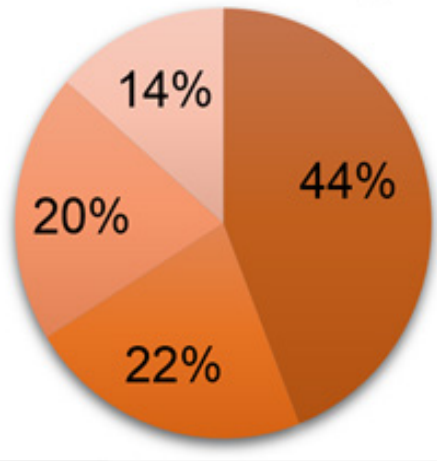

Gambar 2 Sikap negatif guru Bimbingan Konseling SMAN DKI Jakarta

$59(68,6 \%)$ responden yang memiliki sikap negatif terhadap LGBT (Lesbian Gay Biseksual Transjender) terbagi atas beberapa jenis sikap negatif yaitu; $26 \quad(44,07 \%)$ responden memiliki sikap repulsion (menolak) terhadap LGBT (Lesbian Gay Biseksual Transjender), sikap ini merupakan sikap yang sangat negatif dalam jenis sikap negatif, dan secara berurutan sikap kedua dalam skala sikap yaitu $13(22,03 \%)$ responden memiliki sikap pitty (mengasihani), $12(20,34 \%)$ responden memiliki sikap tolerance (mentoleransi) dan yang terakhir $8(13.56 \%)$ responden memiliki sikap acceptance (menerima).

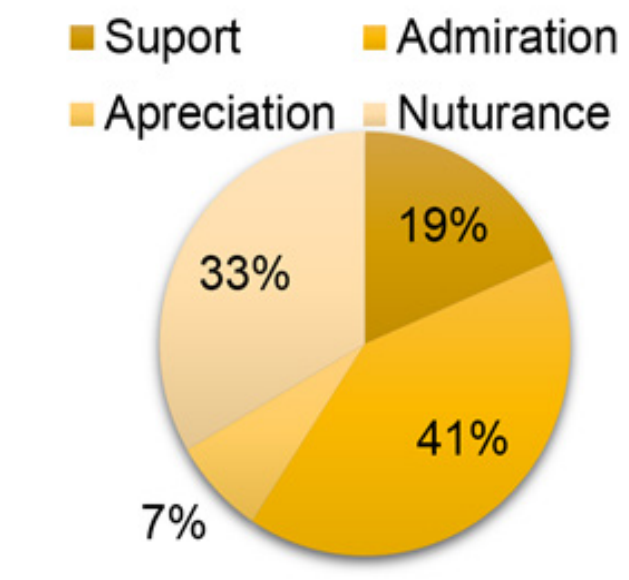

Gambar .3 Sikap positif guru Bimbingan Konseling SMAN DKI Jakarta
$27(31,4 \%)$ responden yang memiliki sikap positif terhadap LGBT terbagi atas beberapa jenis sikap positif yaitu; 11 (40,74\%) responden memiliki sikap Admiration (mengagumi), yang kedua yaitu 9 (33,33\%) responden memiliki sikap Nuturance (Mengasuh) terhadap LGBT, sikap ini merupakan sikap yang sangat positif dalam jenis sikap positif, $5(18,52 \%)$ responden memiliki sikap Suport (mendukung) dan yang terakhir sebanyak $2(7,40 \%)$ responden memiliki sikap Apreciation (mengapresiasi).
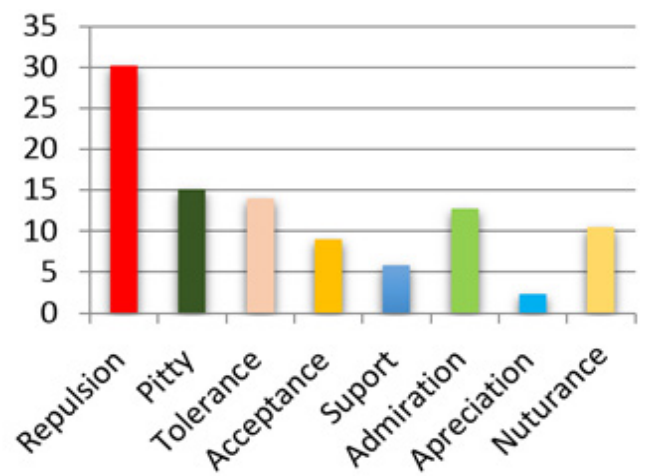

Gambar 4 Sikap guru Bimbingan konseling SMAN DKI Jakarta.

Dapat dilihat dalam Gambar bahwa 3 nilai tertinggi berada pada jenis sikap negatif, dengan sikap repulsion (menolak) sebagai sikap yang sangat negatif sebagai sikap yang tertinggi yang dimiliki responden.

Tabel 1 Sikap Guru Bimbingan Konseling Menurut Jenis Kelamin

\begin{tabular}{llccc}
\hline & \multicolumn{2}{c}{ Laki Laki } & \multicolumn{2}{c}{ Perempuan } \\
\hline \multirow{2}{*}{ Repulsion } & \multicolumn{1}{c}{$\%$} & $\sum$ & $\%$ \\
Pitty & 3 & 16,67 & 10 & 14,70 \\
Tolerance & 1 & 5,55 & 11 & 16,17 \\
Acceptance & 3 & 16,67 & 5 & 7,35 \\
Suport & 0 & 0 & 5 & 7,35 \\
Admiration & 3 & 16,67 & 8 & 11,76 \\
Apreciation & 0 & 0 & 2 & 2,94 \\
Nuturance & 1 & 5,55 & 8 & 11,76 \\
\hline
\end{tabular}


Table 1 menunjukkan bahwa laki-laki memiliki presentase sikap negatif yang lebih tinggi yaitu 38,88 persen dibandingkan dengan perempuan dengan presentase 27,94 persen. Tingkatan sikap tertinggi baik laki-laki maupun perempuan adalah sikap negatif pada kontinum sikap repulsion (menolak).

\section{KESIMPULAN, IMPLIKASI, DAN SA- RAN}

Hasil dari penelitian sikap guru Bimbingan Konseling SMAN DKI Jakarta mengguunakan skala Riddle pada 86 responden di awal tahun 2017 memberikan kesimpulan yaitu:

1. Sikap guru Bimbingan Konseling SMAN DKI Jakarta terhadap LGBT di sekolah secara keseluruhan cenderung negatif dengan $59(68,6 \%)$ responden dan 27 $(31,4 \%)$ responden yang memiliki sikap positif

2. Mayoritas nilai tertinggi sikap yang dimiliki guru Bimbingan Konseling SMAN DKI Jakarta terhadap LGBT di sekolah berada pada jenis sikap negatif dengan $26(44,07 \%)$ responden memiliki sikap repulsion (menolak), 13 (22,03\%) responden memiliki sikap pity (mengasihani), dan $12(20,34 \%)$ responden memiliki sikap tolerance (mentoleransi).

3. Laki-laki memiliki presentase sikap negatif lebih tinggi terhadap LGBT dengan 77,77 persen skor pada sikap negatif, dibandingkan dengan perempuan yaitu 66,16 persen. Sebanyak 38,88 persen lakilaki memiliki sikap repulsion dibandingkan perempuan dengan presentase 27,94 persen dan memiliki presentase sikap positif pada kontinum nuturance lebih kecil yaitu 5,55 persen dibandingkan dengan perempuan yaitu sebesar 11,76 persen

4. Berdasarkan pengetahuan istilah dalam seksualitas, responden yang memiliki pengetahuan istilah dalam seksual lebih tinggi memiliki kecenderungan sikap negatif yang lebih rendah dibandingkan dengan responden yang memiliki pengetahuan istilah dalam seksualitas yang rendah

5. Berdasarkan sumber informasi yang dimiliki oleh responden ditemukan bahwa mayoritas sebanyak $59(68,60 \%)$ responden memiliki sumber informasi non ilmiah lebih banyak daripada sumber informasi yang ilmiah, televisi merupakan media yang paling banyak memberikan informasi berkaitan dengan LGBT dengan resentase 72,09 persen. Responden yang memiliki sumber informasi ilmiah lebih banyak memiliki sikap negatif lebih rendah pada kontinum repulsion dengan 23 persen daripada responden yang memiliki sumber informasi non ilmiah yaitu sebanyak 33 persen. Responden yang memiliki sumber informasi diatas rata-rata memiliki sikap negatif lebih rendah daripada responden yang tidak memiliki sumber informasi yang disebutkan

6. Responden yang memiliki hubungan dengan LGBT memiliki sikap yang lebih negatif dibandingkan mereka yang tidak meimiliki hubungan dengan LGBT

7. Hasil yang di peroleh memberikan dampak bahwa LGBT di sekolah tidak cukup mendapatkan bantuan dari guru Bimbingan Konseling, adanya bias dalam pemberian layanan bimbingan dan konseling di sekolah terhadap LGBT, Jika dihubungkan dengan penelitian norcross maka kemungkinan keberhasilan konseling yang dilakukan guru Bimbingan Konseling kepada LGBT memiliki kecenderungan yang cukup kecil (Norcross, 2002). Secara keseluruhan implikasi sikap yang dimiliki guru Bimbingan Konseling terhadap LGBT adalah, guru Bimbingan Konseling akan memiliki hambatan dalam melaksanakan pelayanan yang efektif, tidak dapat melakukan fungsi advokasinya untuk LGBT dalam mendapatan pendidikan 
dengan layak, serta memberikan andil dalam mendorong LGBT untuk mengalami depresi dan keinginan bunuh diri

Berdasarkan keterbatasan dalam penelitian peneliti memberikan beberapa saran bagi beberapa pihak antara lain:

1. Guru Bimbingan Konseling: Hasil peneiltian dapat dijadikan sebagai self assesment mengenai kesadaran sikap yang dimiliki guru Bimbingan Konseling terhadap LGBT di sekolah, selain itu guru Bimbingan Konseling perlu terbuka untuk dapat melihat dampak dari sikap yang dimilikinya dalam melakukan layanan Bimbingan Konseling kompreshensif di sekolah. Guru Bimbingan Konseling perlu mendapatkan informasi dengan sumber yang lebih ilmiah dengan beberapa kajian atau seminar dengan membaca beberapa jurnal ataupun bukubuku ilmiah yang berkaitan dengan LGBT

2. Mahasiswa program studi Bimbingan Konseling: perlu melakukan penelitian lanjutan untuk dapat mengetahui secara khusus faktor-faktor yang mempengaruhi sikap guru Bimbingan konseling terhadap LGBT di sekolah.

3. Peneliti selanjutnya: Penelitian ini dapat dilakukan ulang dengan wilayah yang lebih luas dengan tingkat kesalahan lebih kecil, selain itu peneliti selanjutnya perlu menangani beberapa keterbatasan penelitian seperti bias dalam penelitian ataupun menggunakan metode yang lebih akurat seperti penggunaan instrumen dengan perangkat elektronik yang dapat mengukur kecepatan seseorang dalam memberikan jawabannya. Selain itu peneliti dapat melakukan penelitian lanjutan seperti gambaran advokasi guru Bimbingan Konseling terhadap LGBT di sekolah, faktor-faktor yang mempengaruhi sikap guru Bimbingan Konseling terhadap LGBT di sekolah, cara yang dapat dilakukan untuk merubah sikap guru Bimbingan Konseling terhadap LGBT di sekolah, layanan yang dapat diberikan untuk sosialisasi antibullying terhadap LGBT di sekolah.

4. Dinas pendidikan: Dinas pendidikan perlu membuat suatu program untuk dapat memberikan informasi yang lebih memadai bagi guru bimbingan dan konseling mengenai seksualitas dalam pembelajaran di sekolah, dan diharapkan peserta yang hadir cukup memiliki keahlian untuk dapat membiimbing rekan kerjanya yang lain atau program dapat dilakukan secara merata dan adil. Dengan menyelenggarakan seminar atau workshop yang berkaitan dengan pelayanan LGBT di sekolah maupun materi mengenai penghapusan kekerasan dan bullying berbasis jender terhadap LGBT disekolah

5. Prodi Bimbingan dan Konseling: Dapat menjadi bahan pertimbangan dalam membentuk/memproduksi calon guru Bimbingan Konseling untuk dapat memiliki sikap yang lebih positif khususnya LGBT sebagai kelompok minoritas dengan mengembangkan metode ataupun perkuliahan dalam profesi bimbingan dan konseling, konseling multikultur, dasar-dasar bimbingan dan konseling

\section{DAFTAR PUSTAKA}

Ajzen, I. (2005). Attitudes, Personality and Behavior . England: Open university McGraw-Hill .

Allen, O. (2010). Lesbian, Gay \& Bisexual Patients: The Issues for Mental Health Practice. Retrieved 10 13, 2016, from Gay \& Lesbian Equality Network.

Arifin, B. S. (2015). Psikologi Sosial. Bandung: Pustaka Setia.

Bishop, S., Williams, K., Currie, J., Kaplan, M., \& Luehr, R. E. (1994). Alone No More. Developing a School Support System for Gay,. Atlanta: Minnesota Department Of Education.

Boxill, I., Galbraith, E., Mitchell, R., \& Russell, R. (2012). National Survey of Attitudes and Perception of Jamaicans Towards Same Sex Relationship. Mona: J-FLAG \& AIDSFREE WORLD. 
Constantine, M. G., \& Sue, D. W. (2005). Strategies for building multicultural competence in mental health and educational setting. Hoboken, New Jersey.: John wiley \& sons. Inc.

Crooks, R., \& Baur, K. (2011). Our Sexuality (Eleventh Edition ed). Belmont: Wadsworth, Cengage Learning.

Davis, C. (2006). School's Out for Bullying Nursing Standart. Proquest Public Health, 20 (21), 24.

Edwards, A. L. (1957). Techniques of Attitude Scale Construction. New York: Aplleton Century Crofts, Inc.

Evans, N. J., \& Wall, V. A. (1991). Beyond Tolerance: Gays, Lesbians and Bisexuals onCampus. Alexandria: American College Personnel Association.

Gerungan, W. (2004). Psikolgi Sosial . Bandung: Refika Aditam.

Laazulva, I. (2013). Menguak Stigma, Kekerasan \& Diskriminasi Pada Lgbt Di Indonesia. (A. P. Yuli Rustinawati, Ed) Jakarta: Arus Pelangi.

Lock, J., \& Kleis, B. (1998). Origin of Homophobia in Male . American Journal of Psychotherapy, 425-436.

Norcross, J. C. (2002). Psychotherapy Relationship That Work. New York: OXFORD University Press.

Raharjo, W. (2007). Homophobia dan penolakan masyarakat serta hubungannya dengan bicultural identity pada convert homoseksual. jurnal penelitian psikologi Universitas Gunadarma, 12, 194-203.

Riddle, B. (1996). Breaking the Silence: Addressing Gay Issues in IndependentSchools. Callifornia: ERIC.

Riddle, D. I. (1994). Homophobia scale. In K. Obear, \& A. Reynolds, Opening Doors to Understanding and Acceptance.a facilitator s guide to presenting workshop on lesbian and gay issues (pp. 34-35). Boston: ACPA Unpublished essay.
Rinehart, S. J., \& Espelage, D. L. (2016). A Multilevel Analysis of School Climate, Homophobic Name-Calling,and Sexual Harassment Victimization/Perpetration. Psychology of Violence, 213.

Sarwono, S. W., \& Meinarno, E. A. (2009). Psikologi Sosial. Jakarta: Salemba Humanika.

Schreier, B. A., \& Lassiter, K. D. (2010). Competencies For Working With Sexual Orientation And Multiple Cultural Identities. In J. A. Cornish, B. A. Schreier, L. I. Nadkarni, L. H. Metzger, \& E. R. Rodolfa (Eds), Handbook Of Multicultural Counseling Competencies (p. 291). New Jersey: John Wiley \& Sons.

Soekrisno, S., \& Adryanto, M. (1999). Psikologi Sosial. Jakarta: Erlangga.

Sue, D. W., \& Sue, D. (2013). Counseling the culturally diverse. Theory and practice. Hoboken, New Jersey: John Wiley \& Sons, Inc.

Suzuki, L. A., \& Ponterotto, J. G. (Eds). (2008). Handbook Of Multicultural Assesment, Clinical, Psychological And Educational Application. San Francisco: John Wiley \&Sons. Inc.

Tayor, C., \& Petter, T. (2009). youth speak up about homophobia and transphobia. the first national climate survey on homophobia in canadian schools phase one report. Manitoba: Egale Canada Human Right Trust.

Tollerud, T. R., \& Slabon, L. S. (2009). Cross Cultural Awarness and Social Justice in Counseling. (C. M. Carlson, Ed) London: Routledge, Taylor \& Francis Group.

Ward, V. G., \& Riddle, D. I. (2014). Weaving Soft Skills Development into Everyday Employment Services in Canada. CANNEXUS.

Warwick, I., \& R. Goodrich, P. (2006). Homophobic Bullying and School-responding to The Challenge. youth \& policy, 91, 91, 59-73.

Wong, D. (2007). Rethinking the coming home alternative: hybridization and coming out 
politics in Hong Kong's anti-homophobia parades. Inter-Asia Cultural Studies, 600616.

Yuliani, S. (2013). Diskriminasi Waria dalam Memperoleh Pelayanan Publik Dasar: Tinjauan dari Perspektif Human Governance. Seminar Internasional ASPA$I A P A$ "Innovative Governance. Semarang: UB Press and Faculty of Administrative Science University of Brawijaya.

Yusuf, S., \& Nurihsan, A. J. (2011). Landasan Bimbingan \& Konseling. Bandung: Rosda. 


\section{Pernyataan istilah dalam seksualitas}

a. Orientasi seksual merupakan perasaan yang meliputi emosi, romantis, dan ketertarikan seksual terhadap laki-laki, perempuan atau keduanya.

b. Hanya seorang homoseks yang melakukan kegiatan seksual sesama jenis.

c. Identitas seksual adalah sebagai kesadaran seseorang akan hubungan dengan kecenderungan seksual yang dimiliki.

\section{Pernyataan Instrumen Penelitian}

a. LGBT adalah pendosa.

b. LGBT adalah individu yang perlu dikasihani dan membutuhkan bantuan

c. LGBT adalah individu yang perlu dilindungi atas perlilakunya yang belum dewasa

d. Saya mengakui bahwa LGBT dapat ikut serta dalam kehidupan bermasyarakat sejauh mereka tidak memperlihatkan identitas LGBT mereka secara terbuka

e. Kebencian terhadap LGBT merupakan hal yang salah.

f. LGBT adalah orang-orang yang pantas untuk dikagumi atas karya-karya yang mereka hasilkan

g. Menghargai keberagaman orientasi dan identitas seksual adalah hal yang penting bagi masyarakat yang lebih adil.

h. Mereka yang LGBT bukan hanya perlu diakui namun juga perlu diperlakukan secara setara dalam berbagai bidang 